\title{
E-COMMERCE IN INDIA: E- PAYMENT METHODS, TRENDS AND CHALLENGES
}

\author{
Dr.G.Damodhar \\ Department of Commerce, \\ SVU College of CM\&CS \\ S V University Tirupati \\ Andhara Pradesh, India
}

\begin{abstract}
E-commerce provides the potential of shopping for and commerce product and services on the web and different on-line environments.

In Ecommerce surroundings, payments take kind the shape of cash exchange in an electronic form and known as electronic payment. E-Payment system is secure there ought to be no threat to the user E-Payments has created their approach easier through open-end credit, master card, ECS, EFT, RTGS and NEFT. Digital case and UPI payments, payment are often carried with involvement of third parties; it makes E-payment at any time through the web on to the transfer settlement and type E-business surroundings. Electronic payment revolutionized the business process by reducing the work, dealing prices, and labour value. This paper an endeavour to E-payment trends is driving through Ecommerce in Bharat. Being user friendly and fewer long than manual process, it helps concern to expand its market reach/expansion of the E-commerce.
\end{abstract}

Keywords- E-Payment, debit cards, smart card, Digital Wallet, UPI payments.

\section{INTRODUCTION}

The most well-liked definition of E-Commerce relies on the web perspective of the conducted business. E-commerce provides the potential of shopping for and commercialism product, data and services on the net and alternative on-line environments. As for any commerce activity the problem of safe and reliable cash exchange between transacting parties is crucial. In E-commerce surroundings, payments take kind the shape of cash exchange in an electronic form, and square measure so referred to as Electronic Payment. E-commerce sector has been the backbone of each economy whether or not developed or rising. It plans and implements the economic reforms. Any modification during this sector through the adoption of technology can have an intensive impact on growth. Nowadays, banks square measure seeking unconventional ways that to produce and differentiate amongst their numerous services. Each company further as retail

\author{
Dr.T.Suneetha \\ Department of Commerce \\ SPW Degree \& PG College \\ Tirupathi-517502 \\ Andhara Pradesh, India
}

customers are not any longer willing to queue in banks or assist the phone, for the essential banking services. They need and expect a facility to conduct their banking activities at any time and place. Plastic cash (Credit Cards, DebitCardsand good Cards) net banking togetherwith electroni cpaymentsservices, online investments, online commerce acco unts, electronic fund transfer and clearing services, branch networking, Phone banking; mobile applications and bill fold square measure a number of the recent product and services acting because the drivers to the expansion of banking sector. Accounting and data technology are constant companions since the times of tabulating machines. Accounting an art and science of monetary data has evolved in cycle with data technology. The term digital accounting s utilized in this book to capture the changes within the accounting cycles, processes and functions.



E-commerce is a generic term for delivery of banking/ financial services and products through electronic channels, such as the Automated Teller Machines (ATMs), the phone, the web, the social media, the mobile, etc. The industry in Asian country is more and more increasing. The alleviation of the economy has created a competitive 


\section{International Journal of Engineering Applied Sciences and Technology, 2020 \\ Vol. 5, Issue 7, ISSN No. 2455-2143, Pages 275-279 \\ Published Online November 2020 in IJEAST (http://www.ijeast.com)}

culture that has taken the service sector, notably the banking sector by storm. The banking sector has been the backbone of each rising economy. It plans and implements the economic reforms. Any modification during this sector through the adoption of technology can have a sweeping impact on associate degree associate degree growth. The advancement of data assortment, storage, process and transmission technologies have wedged all aspects of the banking activity. ATMs, plastic cash (Credit Cards, Debit Cards and sensible Cards), on-line assortment and UPI payment services, on-line investments (Deposits and Mutual Funds), on-line De-mat and commercialism accounts, Electronic Funds Transfer (ETF) and clearing services, branch networking, phone banking, mobile applications and pocket book, and web banking.

\section{OBJECTIVES OF THE STUDY}

The main objectives of the study are

- Trends of Digital Payments in India.

- To identify the e payment methods in India.

- To build awareness on various methods of on-line

- $\quad$ and mobile payment systems.

\section{TRENDS OF E- PAYMENTS IN INDIA}

- India's payment system significantly, its digital payments system has been evolving robustly over the past a few years, spurred by developments in data and communication technology and fostered and in consonance with the trail visualized by the Reserve Bank of India.

- As a part of this vision, the National Payments Corporation of Asian country (NPCI) was established in 2008 has been spear heading the event of the retail payments system.

- Important milestones earned during this overall method of development of the payments system embrace the introduction of MICR clearing within the early Nineteen Eighties, Electronic Clearing Service and Electronic Funds Transfer within the Nineteen Nineties, supply of credit and debit cards by banks within the Nineteen Nineties, the National monetary Switch in 2003 that led to interconnectivity of ATMs across the country, the RTGS and NEFT in 2004, the Cheque Truncation System (CTS) in 2008, the second issue authentication for the card not presente group action in 2009 and the new RTGS with increased options in 2013.

- Furthermore, non-bank entities are introduced within the supply of pre-paid instruments (PPI), together with mobile and digital wallets. These measures are complemented by important initiatives by the NPCI together with the launching of grid-wise operations of CTS, ability on NACH, IMPS, NFS, RuPay (a domestic card payment network), APBS and AEPS (which area unit a very important a part of the monetary inclusion process), National Unified USSD Platform (NUUP), UPI and also the BHIM application.

- Many of those achievements, significantly given their pan-India coverage, area unit so notable from a crosscountry perspective, together with the $\mathrm{T}$ or $\mathrm{T}+1$ total clearing of cheques enabled by CTS and also the financial organization infrastructure, the NEFT, the IMPS, mobile banking/payments and also the security aspects of card payments.

These developments capture the evolution of the Digital Payments scheme within the country. This was followed by a serious initiative by Government of Asian country that found out the Committee Digital Payments in August 2016 beneath the place of Shri. Ratan P. Watal, Principal consultant, NITI Aayog..

\section{E- PAYMENT METHODS IN INDIA}

The most in style definition of e-commerce relies on the web perspective of the conducted business. E-commerce provides the aptitude of shopping for and mercantilism merchandise, data and services on the web and different on-line environments. As for any commercialism activity, the problem of safe and reliable cash exchange between transacting parties is crucial. In associate degree e-commerce atmosphere, payments take kind the shape of cash exchange in associate degree electronic form, and area unit so known as electronic payments. Electronic payments area unit associate degree integral a part of e-commerce and area unit one in all its most important as- pacts. ATMs, plastic cash Credit Cards, Debit Cards and sensible Cards, on-line assortment and UPI payment services, on-line investments (Deposits and Mutual Funds), the following methods are.

\section{CREDIT CARDS:}

Master card may be a plastic card issued to the users to Lenten tide cash for purchase of products and services. A master card may be a piece of plastic, 3-1/8inches by $2-1 / 8$ inches in size that carries data that enable you to form purchase currently get hold of them later. Credit cards from visa amplifier card or the other network enable you to get hold of purchase or services by borrowing from the master card company. Tobuy merchandise from businessperson Unite d Nations agency settle for master card like businessperson has master card reader to buy the payment group action to withdraw money from ATM. 


\section{International Journal of Engineering Applied Sciences and Technology, 2020 \\ Vol. 5, Issue 7, ISSN No. 2455-2143, Pages 275-279 \\ Published Online November 2020 in IJEAST (http://www.ijeast.com)}

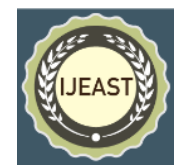

The client kind the and asking address main points and be assured of payment. The master card payment on the web network may be classified into 3 types:

(a) Payment using plain credit card details

(b) Payment using encrypted credit card details

Payment using third party verification

\section{DEBIT CARD:}

Debit card can be a postpaid card and in addition to called ATM card. A private wants to open associate degree account with the provision bank which supplies optimistic identification with a personal id range, once he makes an acquisition he enter his PIN number on look pin pad. once the cardboard is slurped through the electronic terminal it dial the acquire a banking industry either master card or visa card that validate the pin and finds out from the provision bank whether or not to simply accept or decline the group action the client will never overspend as a outcome of the system reject any group action that exceeds the balance in his account the bank never face a default as a result of the quantity spent is debited directly from the customer account With virtually each checking account you are issued a optimistic identification.

\section{SMART CARD:}

Smart card was $1^{\text {st }}$ launched in Europe most of those methodology area unit called hold on worth card. Smart card is relating to the scale of a master card made from a plastic with associate degree entrenched silicon chip that holds vital monetary and private data. The silicon chip is loaded with the relevant data and infrequently recharged. in addition to those objects of knowledge systems are developed to store money onto the chip. The money on the cardboard is saved in associate degree encrypted kind and is protected by a secret to confirm the protection of the positive identification resolution. So as to pay via sensible credit is important to introduce the cardboard into a hardware terminal. The device wants a particular key from the provision bank to start out a cash transfer in either direction smart cards may be reversible and disposable.

\section{Digital Wallet (Electronic wallet):}

Electronic wallets being terribly helpful for frequent internet buyers square measure commercially out there for pocket, palm-sized, handheld, and desktop PCs. they provide a secure, convenient, and moveable tool for on-line searching. They store personal and money info like master cards, passwords, PINs, and far a lot of. To facilitate the credit-card order method, several firms square measure introducing electronic billfold billfold permit you to stay track of your charge and shipping info in order that it are often entered with one click at taking part merchants' sites.E-wallets can even store e checks, e-cash and your credit-card info for multiple cards.

\section{Electronic Cheque:}

Electronic cheque is messages that contain all the data that's found on a standard Cheque however it uses digital signature for language and endorsing and has digital certificate to evidence checking account. There square measure several websites that settle for Electronic Cheque. Associate in Nursing electronic payment method that resembles the operate of paper cheques however offers nice security and a lot of options. Electronic checks square measure usually utilized in orders processed on-line and square measure ruled by similar laws that apply to paper checks. Electronic checks provide protecting measures like aunthentification and digital signatures to safeguard digital transactions.

\section{NET BILL:}

Net Bill may be a small payment system. Internet bill payment system uses web for getting merchandise and services and makes secure and economical payments for them. World Wide Web bill server maintains account for each shoppers and merchants that permits customers to pay merchants for merchandise to be delivered. The products square measure deliveredindigital kind. There's cash tool package tha $t$ verifies receipts of products. So, internet bill system of electronic payment allows the communication between cash tool, the business person server and internet bill server.

\section{E-CASH:}

E-cash was a digital-based system that facilitated the transfer of funds anonymously. Parallel to regular money, e-cash allows transactions among customers while not the requirement for banks and different third parties. Whilst it is used, e-cash is transfer straight and in real time to the taking part merchants and hawking machines. Electronic cashes a secure and suitable a variety of to bills and money. E-cash typically operates on a smartcard, which incorporates Associate in attention embed to micro chip.

The micro chip stores money worth and also the safety features that build electronic transactions secure. Once e money created by one bank is accepted by different reconciliation should occur with none drawback money should be storable and due. Most E-cash is transferred directly from the customer's desktop to the merchant's website. Therefore, ecash transactions typically need no remote authorization or personal identification. Now that many companies and freelancers are doing business with others all over the world, e-cash has provided a way to collect and send any type of currency required.

8. Unified Payments Interface (UPI) may be a system that powers multiple bank accounts into one mobile application 


\section{International Journal of Engineering Applied Sciences and Technology, 2020 \\ Vol. 5, Issue 7, ISSN No. 2455-2143, Pages 275-279 \\ Published Online November 2020 in IJEAST (http://www.ijeast.com)}

(of any taking part bank), merging many banking options, seamless fund routing \& businessperson payments into one hood. It additionally caters to the "Peer to Peer" collect request which might be scheduled and paid as per demand and convenience. The Unified Payment Interface (UPI) can be thought of like an email ID for your money. It will be an unique identifier that your bank uses to transfer money and make payments using the IMPS (Immediate Payments Service). IMPS are faster than NEFT and lets you transfer money immediately and unlike NEFT, it works $24 \times 7$. This means that the online payments will become much easier without requiring a digital wallet or credit or debit card. Unified Payment Interface is an initiative by National Payments Corporation of India ${ }^{e e}$ s ( $\underline{\mathrm{NPCI}}$ ), set up with the support of the Reserve Bank of India and Indian Banks Association (IBA). The NCPI operates the Rupay payments infrastructure that - like Visa and MasterCard allows different banks to interconnect and transfer funds. SBI Pay, HDFC Bank Mobile Banking, ICICI Pockets: Android, iOS PhonePe: $\underline{\text { Android }}$

\section{Mobile Payments with reference to the Banking Systems}

Mobile Payment supports any dealing with a value that's conducted through a mobile telecommunication network. A wireless payment system refers to Associate in Nursing electronic payment system that has wireless primarily based electronic payment solutions to support purpose of sale and /or purpose of service payment transactions over wireless or web through various mobile users devices, like cellular telephones, sensible phones and mobile terminals. Doing money transactions via mobile phones would eliminate the necessity for auxiliary payment instruments (like POS devices), whereas exploitation safety features of the SIM card (as a sensible card) would yield to an excellent level of security and irresponsibleness. A mobile payment service contains of all technologies that square measure offered to user still as all tasks that the payment service provider(s) perform to commit payment transactions like money, credit card, or portable billfold. In payments of Typical usage entails the user electing to create a mobile payment, being connected to a server via the mobile device to perform authentication and authorization, and after being given with confirmation of the finished dealing. whereas planning and developing any payment system it is necessary to think about some small print like communication between businessperson and shopper, trust, security, simple payment, low dealing prices just in case of Credit cards. Preparation of fortunate mobile payment system is results of cooperation of various players, whereas every of them have totally different expectations. Bills/Invoices mobile payments usually give access to account primarily based payments like cash transfers, web banking payments, or direct debit assignments. The most players include:

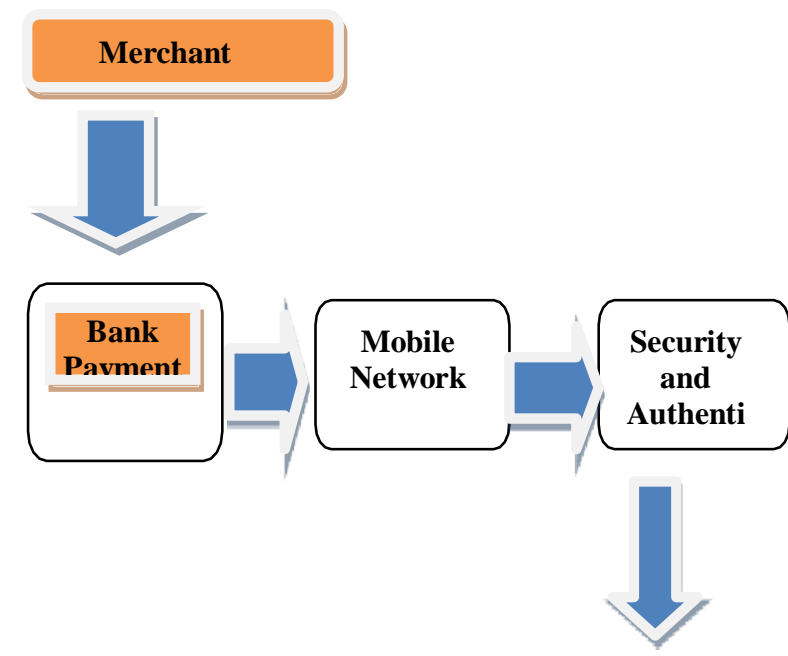

Users

Customer: Buyer expectations embrace having the ability to pay anyplace, anytime and in any currency, wide accessibility of the new services, support for micropayments equally as macro payments and low any charges

MobileNetwork Operator Its expectations embrace adding price to existing services, to increase shopper loyalty, new revenue channels and to increase the revenue per user.

Bank:

Bank's

expectations embrace disapproval and shopper loyalty, new business cases, secure payment service and decrease of frauds and to new payment ways.

\section{CONCLUSION}

Electronic payment refers to the method of payment that does not embody physical money or cheques. It includes open-end credit, master card, smart card, e-wallet, UPI payments etc. E-Commerce has its main link in its development online within the use of payment ways, a number of that were analysed during this work. The risk to the net payments is the every of payments information, personal information and dishonourable rejection on the part of customers. Therefore, and till the utilization of electronic signatures is wide unfold, we tend to should use the technology out there for the instant to ensure an affordable minimum level of security on the network. If the shopper needs to take care of privacy, then they select those payment ways that guarantee the next level of privacy like E-cash or web Bill Checks. If the priority is security, they must use, sensible Cards. Each customers and repair suppliers will get pleasure from e-payment systems resulting in increase national fight within the longterm. The undefeated implementations of electronic payment systems depends on however the safety and privacy 
Published Online November 2020 in IJEAST (http://www.ijeast.com)

dimensions perceived by customers additionally as sellers are popularly managed, successively would improve the market confidence within the system.

\section{REFERENCES}

1.Chhabra, T.N., Suri, R.K., Verma, Sanjiv (2006). ECommerce. Dhanpat Rai \& Co. (P) Ltd. (pp.306-328).

2.Whiteley, David, (2007). e-Commerce, Strategy, Technologies and Applications. Tata McGraw-Hill Publishing Company Limited. (PP.200-201).

3.Bhasker, Bharat (2013). Electronic Commerce, Framework, Technologies and Applications. McGraw Hill Education (India) Private Limited., (pp.9.2-9.16).

4.Madan, Sushila (2013). E-Commerce, Mayur Paperbacks. ( p p.4.4-4.35).

5.http:/www.niti.gov.in

6.http:/www.fraudlabs.com. 